\title{
Yerel Yazındaki "İsse Angaje Olma Makaleleri” nin Sosyal Ağ Analizi İle İncelenmesi (Examining "Work/Employee/Job Engagement Articles" in Domestic Literature by Social Network Analysis)
}

\section{F. Nazlı SAYĞAN YAĞIZ (iD) a}

a Marmara Üniversitesi, Sosyal Bilimler Enstitüsü, İstanbul, Türkiye. nazlisaygan@gmail.com

\begin{tabular}{ll}
\hline MAKALE BİLGísi & ÖZET \\
\hline $\begin{array}{l}\text { Anahtar Kelimeler: } \\
\text { İşe Angaje Olma }\end{array}$ & $\begin{array}{l}\text { Amaç - Bu çalışmanın amacı yerel yazında yönetim ve organizasyon alanında yer alan "işe angaje } \\
\text { olma" makalelerinin bibliyometrik yöntemle ele alınmasıdır. }\end{array}$ \\
Bibliyometri & Yöntem - Çalı̧̧ma kapsamında alan yazında yer alan 97 makale değerlendirmeye tabi tutulmuştur. Bu \\
Sosyal Ağ Analizi & $\begin{array}{l}\text { kapsamda ilgili makalelerin anahtar sözcüklerinden yola çıkılarak sosyal ağ analizi yapıllmış ve anahtar } \\
\text { sözcüklerin ağ haritası görselleştirilmiştir. }\end{array}$
\end{tabular}

Gönderilme Tarihi 17 Ağustos 2020

Revizyon Tarihi 8 Ocak 2021

Kabul Tarihi 10 Mart 2021

Makale Kategorisi:

Araştırma Makalesi

Bulgular - Yerel yazındaki bilgi ağında hangi anahtar sözcüklerin merkezileşmiş konumda olduğu ve hangilerinin aracılık rolü üstlendiği belirlenmiştir. Bu şekilde yerel yazındaki yönetim ve organizasyon alanındaki "işe angaje olma" makalelerindeki odak çalışma konuları ortaya çıkarılmıştır. Çoğunlukla makalelerin işten ayrılma niyeti üzerine odaklandığı gözlemlenmektedir.

Tartışma - Çalışma kapsamında elde edilen bulgular yorumlanarak yerel yazındaki eğilimlere ilişkin genel bir değerlendirme yapılmıştır. Bu doğrultuda çalışmanın ilgili konuda yapılabilecek gelecek çalışmalara "boşluklar" hakkında bilgi verebileceğine yönelik katkı sunabileceği söylenebilir.

\begin{tabular}{|c|c|}
\hline ARTICLE INFO & ABSTRACT \\
\hline Keywords: & arpose - The aim of this study is to deal with domestic "work/job/employee engagement" articles in \\
\hline Work Engagement & he field of management and organization by bibliometric method. \\
\hline $\begin{array}{l}\text { Bibliometry } \\
\text { Social Network Analysis }\end{array}$ & $\begin{array}{l}\text { Design/methodology/approach - Within the scope of the study, } 97 \text { articles in the literature are } \\
\text { evaluated. In this context, based on the keywords of the relevant articles, social network analysis is }\end{array}$ \\
\hline Received 17 August 2020 & made and the network map of the keywords is visualized. \\
\hline Revised 8 January 2021 & Findings - It is determined which keywords are centralized and which have bridging roles in the \\
\hline Accepted 10 March 2021 & $\begin{array}{l}\text { knowledge network in domestic literature. Therefore, the focused research topics of domestic } \\
\text { "work/job/employee engagement" articles in the field of management and organization are revealed. It } \\
\text { is observed that the articles mostly focus on turn over intention. }\end{array}$ \\
\hline $\begin{array}{l}\text { Article Classification: } \\
\text { Research Article }\end{array}$ & $\begin{array}{l}\text { Discussion - A general evaluation has been made regarding to the trends in domestic literature by } \\
\text { interpreting the findings obtained within the scope of the study. Hence, it can be said that the study can } \\
\text { contribute to the future studies which are on the relevant subject by providing knowledge about the } \\
\text { "gaps". }\end{array}$ \\
\hline
\end{tabular}

\section{GİRIŞ}

Günümüz rekabet koşullarında, örgütlerin çalışanlarda aradığı nitelikler arasına işe angaje olma kavramı da girmiştir (Bakker ve Demerouti, 2008; Bakker vd., 2011: 4)). İşe angaje olma, çalışanın işine gönülden bağlı olması, istekle ve hevesle tüm gücünü ve kapasitesini işine yöneltmesi anlamını taşımaktadır (Schaufeli vd., 2002). İşe angaje olmanın işletmenin rekabetçi gücünü arttırıcı yönde birçok fayda sağladığı söylenebilmektedir. Yazında, işe angaje olmanın çalışan performansını ve verimliğini arttırdığına dair birçok çalışma mevcuttur (Bakker ve Bal, 2010; Hanaysha 2016). Ayrıca çalışanın örgüte olan sadakatini arttırdığına ve işten ayrılma niyetini azalttığına dair bulgular içeren çalışmalar da vardır (Bal vd., 2013; Ibrahim ve Al Falasi, 2014). Örgütlerin insan kaynakları bölümleri çalışanların işe angaje olmalarını arttırıcı yönde politikalar geliştirmektedir. Yönetim ve organizasyon yazınında da çok sayıda çalışmanın (Arıkan ve Çankır, 2019; Başaran, 2017; Bekmezci ve Yıldız, 2019) işe angaje olma olgusu üzerinde odaklandığı gözlemlenmektedir. 
Çalışma kapsamında, yerel yazındaki işe angaje olma makaleleri değerlendirmeye tabi tutularak işe angaje olmaya odaklanan makalelerin tematik gelişimi ve bilgi yapısı ortaya çıkarılmaya çalışılmaktadır.

Yerel yazında işe angaje olma olgusuna ilişkin herhangi bir bibliyometrik çalışmaya rastlanmamıştır. İşe angaje olma olgusuna odaklanan bu çalışma, bibliyometrik bir araştırma niteliği taşımaktadır. Bibliyometrik çalışmalar, yazının zaman içerisindeki gelişimini göstermesi, yazarların eğilimlerinin ne yönde olduğunu yansıtması ve yazında odaklanılan konulara ilişkin tespitlerin yapılmasına olanak vermesi açısından önemlidir. Sosyal ağ analizi bibliyometrik çalışmalarda kullanılan yöntemlerden biridir. Çalışma kapsamında 97 adet işe angaje olma makalesinin 140 adet anahtar sözcüğünden yola çıkılarak sosyal ağ analizi yapılmıştır. Ayrıca sosyal ağ analizi ile anahtar sözcüklerin ağ haritası görselleştirilmiştir. Böylece yerel yazında işe angaje olma kavramının en çok hangi kavramlarla ilişkilendirildiği, hangi kavramların aracılık rolü üstlenerek birbiriyle ilişkisi olmayan kavramları bir araya getirdiği tespit edilmiş ve yerel yazına ilişkin genel bir değerlendirme yapılabilmiştir. Böylece gelecekte işe angaje olma konusu üzerine çalışacak ve araştırma sorusu oluşturacak araştırmalara yazındaki eğilimin ne yönde olduğuna ilişkin bir fikir verebilmekte ve onlara yol gösterebilmektedir.

\section{KAVRAMSAL ÇERÇEVE}

Pozitif psikolojinin incelediği bir konu olan angaje olma olgusu yönetim yazınına Kahn (1990)'ın "Psychologıcal Condıtıons of Personal Engagement and Dısengagement at Work" adlı çalışması ile girmiştir. Kahn (1990: 694) çalışmasında, bireylerin örgütteki rollerini sergilerken kendilerini fiziksel, bilişsel ve duygusal olarak işlerine verme derecelerinin değişiklik gösterdiğini belirtmektedir. Kahn (1990)'a göre bu değişiklik, bireylerin örgütte üstlendikleri rolleri içselleştirip içselleştirememelerinden yani kendilerini işlerine verme derecelerinin değişmesinden kaynaklanabilmektedir. Bazı bireyler örgütte üstlendikleri rolleri içselleştirmekte ve işleriyle uyum içerisinde olduklarını düşünebilmektedirler. Bazıları ise üstlendikleri rolleri özümsememekte ve işleriyle kendi benliklerini ayrı tutabilmektedir. Örgütteki rollerini isteksiz bir şekilde yerine getiren, üstlendikleri rolleri özümsemeyen bireyler yaptıkları işten keyif almamakta, yüksek enerjilerini iş yerinde baskılamakta, işe yeterince emek harcamamakta, iş üzerine düşünmemekte ve işi sevmeden adeta bir robot gibi yapmaktadır. Örgütteki rollerini istekli bir şekilde yerine getiren rollerini içselleştirmiş bireyler ise işlerini yüksek enerjiyle, istekli bir şekilde yapmakta ve çok çalışmaktan keyif almaktadır. Kahn (1990: 700702) bu farklılıklardan yola çıkarak fiziksel, bilişsel ve duygusal olarak kendini işe veren çalışanları işe angaje olan çalışanlar olarak nitelendirmekte ve işe angaje olmayı bireyin "fiziksel (physical)", "bilişsel (cognitive)" ve "duygusal (emotional)" olarak kendini işe vermesi olarak tanımlamaktadır. Bireylerin fiziksel olarak kendilerini işe vermeleri iş için yüksek enerji harcamaları ve iş yapmaktan kaçınmamaları, bilişsel olarak kendilerini işe vermeleri işleri üzerine düşünüp yaratıcı fikirler üretmeleri ve işlerini geliştirmeye çalışmaları ve duygusal olarak kendilerini işe vermeleri ise işleriyle ilgili diğer insanlarla iletişim kurmaları, diğer insanların duygu ve düşüncelerini anlayabilmeleri ve onlarla empati kurmaları anlamına gelmektedir.

Schaufeli vd.'ye göre, (2002: 74) işe angaje olma, çalışanın işine karşı hissettiği olumlu ruh halini yansıtan bir kavramdır. "Dinçlik", "adanma" ve "özümseme" olmak üzere üç boyutla karakterize edilmektedir. "Dinçlik (vigor)", bireyin yüksek enerjiye sahip olması ve örgütsel amaçlara ulaşmak için istekli bir şekilde ve yüksek enerjiyle çaba göstermesi anlamına gelmektedir. "Adanma (dedication)" bireyin işini emek harcamaya değer önemli ve ilgi çekici bir uğraş olarak nitelendirmesi ve kendini işine adaması olarak tanımlanmaktadır. "Özümseme (absorbtion)" ise bireyin işiyle uğraşırken sadece işiyle ilgili konulara yoğunlaşması ve iş dışındaki konuların dikkatini dağıtmaması anlamına gelmektedir (Schaufeli ve Bakker, 2010; Schaufeli, vd., 2002, 74; Bakker vd., 2011: 5). Schaufeli vd.'ye göre, işe angaje olan çalışanlar işlerini sevdikleri ve eğlenceli buldukları için yapmakta ve çok çalışmaktadır. Hırs, diğer insanları geçme isteği veya kıskançlık gibi içsel dürtüler onların çok çalışmalarına sebep olmamaktadır. Çalışmadan aldıkları zevk onların çok çalışmalarının altında yatan temel sebeplerden biridir. Gorgievski vd.(2010)'nin çalışmasına göre, işe angaje olan çalışanlar çok çalışmalarına rağmen işkolik olarak nitelendirilememektedir. İşkoliklerin aksine işe angaje olan bireyler, yoğun bir iş gününün ardından kendilerini yorgun hissetmelerine rağmen sevdikleri bir işi yaparak yorgun düştükleri için yorgunluklarından şikayet etmemektedirler. İse angaje olan çalışanların yoğun bir iş gününün ardından şikayet etmemeleri gibi diğer olumlu tutum ve davranışları takdir görmelerine, yaptıkları işte başarı ve tanınırlık elde etmelerine sebep olabilmektedir. 
Maslach ve Leiter (2008)'in çalışmalarında ise işe angaje olma kavramı tükenmişlik kavramından yola çıkılarak açıklanmaktadır. Maslach ve Leiter'e (2008) göre, işe angaje olma tükenmişliğin zıttını ifade etmektedir. Tükenmişlik, uzun süreli iş stresinin bir sonucu olarak bireyde oluşan psikolojik sendromdur. Tükenmişlik "yorgunluk (exhaustion)", "siniklik (cynisim)" ve "yetersizlik (inefficacy)" olmak üzere üç alt boyut içermektedir. İşe angaje olma kavramı ise bu üç boyutun zıttı olan "enerji (energy)", "katılım (involvement)", "yeterlilik, (efficacy)" alt boyutlarıyla açiklanmaktadır. "Yorgunluk" bireyin işini yaparken kendini yorgun hissetmesi, fiziksel ve duygusal kaynaklarını büyük ölçüde tüketmesi anlamına gelirken "enerji" bireyin işle ilgili sorumluluklarını yerine getirirken yüksek enerjiye sahip olması anlamına gelmektedir. "Siniklik" bireyin işine karşı duyarsızlaşması, ilgisizleşmesi ve işiyle ilgili konularda olumsuz, aşırı tepkiler vermesi anlamına gelirken, "katılım" bireyin işine önem vermesi ve işini kendini vererek yapması anlamına gelmektedir. Son boyut olan "yetersizlik" ise bireyin iş başarısıyla ilgili olumsuz değerlendirme yapması ve kendini yetersiz hissetmesi anlamına gelirken "yeterlilik" bireyin kendini işinde başarılı ve yeterli hissetmesi anlamına gelmektedir.

Saks (2006) "Antecedents and consequences of employee engagement" adlı çalışmasında, angaje olma kavramının "işe angaje olma" ve "örgüte angaje olma" şeklinde ikiye ayrıldığının bulgusuna ulaşmıştır. Çalışmada, işe angaje olma ve örgüte angaje olma kavramlarının farklı öncül ve sonuçlara sahip olduğu tespit edilmiş ve birbirleriyle ilişkili olmalarına rağmen farklı kavramlar oldukları üzerinde durulmuştur. Saks (2006)'a göre, işe angaje olma bireyin işini sevmesi, kendini işine vermesi ve işini yaparken zamanın nasıl geçtiğini unutması iken, örgüte angaje olma bireyin örgütü sevmesi, örgüt için gönülden çalışması ve örgütün bir üyesi olmaktan ötürü mutluluk ve heyecan duymasıdır (Saks, 2006: 617). Bu çalışma kapsamında "işe angaje olma" üzerinde durularak "örgüte angaje olma" konusu kapsam dışı bırakılmıştır.

\section{YÖNTEM}

Bibliyometrik bir yöntemle ele alınan bu çalışma kapsamında, yönetim ve organizasyon alanındaki işe angaje olma makalelerinin anahtar sözcüklerinden yola çıkılarak sosyal ağ analizi yapılmıştır. Sosyal ağ analizi ile anahtar sözcüklerin ağ haritası görselleştirilmiştir. Makale taraması esnasında Google Scholar, Marmara Üniversitesi ve Ulakbim veritabanı kullanılmıştır. "Job/work/employee engagement" kavramlarının Türkçe'ye birçok farklı sözcükle çevrilmiş olması sebebiyle makaleler "job/work/employee engagement" anahtar sözcükleriyle aranmıştır. Makalelerin Özet bölümünün altında yer alan "İngilizce Anahtar Sözcükler" (Keywords) kısmında bu üç anahtar sözcükten her hangi birine yer veren yerel makaleler kayıt altına alınmıştır. Sonrasında eğitim alanına ilişkin dergilerde yayınlanan makalelerin de kayıt altına alındığ tespit edilerek bu makaleler elenmiş ve sadece yönetim ve organizasyon alanındaki doksan yedi adet makale değerlendirmeye alınmıştır.

Bibliyometrik yöntem, matematiksel ve istatiksel yöntemlerin kitap, dergi ve makale gibi yazılı iletişim araçları üzerine uygulanmasıdır. Bibliyometrik yöntem ile yazında yer alan makaleler incelenerek makaleler arasındaki ilişkiler sayısal olarak analiz edilebilmekte, ilgili yazın ile ilgili genel bir çıkarım yapılabilmekte, yazının zaman içinde nasıl bir gelişim gösterdiği veya bu yazına ilişkin eğilimin ne yönde geliştiği tespit edilebilmektedir (Broadus, 1987: 373-374).

Sosyal ağ analizi, bibliyometrik çalışmalarda son yıllarda kullanılmaya başlanan bir yöntemdir. 2008 yılından itibaren yerel yazında da kullanılmaya başlandığı gözlemlenmektedir (Sayğan Tunçay vd., 2015; Turgut ve Beğenirbaş 2016). Sosyal ağ analizi sosyal ağların incelenmesini ve analiz edilmesini sağlayan bir analiz yönetimidir. Sosyal ağlar, birbiriyle etkileşim içinde bulunan birimlerin veya aktörlerin ilişkilerini ve aralarındaki bağları gösteren yapılardır (Wasserman ve Faust, 1994: 4-7). Bu çalışma kapsamında birimler anahtar sözcüklerdir. Anahtar sözcükler arasındaki ilişkiler ve bağlar ortaya çıkarılmaya ve görsel hale getirilmeye çalışılmaktadır. Bu ilişkileri ortaya çıkarmaya yönelik olarak sosyal ağ analizinde kullanılan belirli ölçütler vardır. Bu ölçütlerden biri olan merkezilik (centrality) analizde kullanılan temel ölçütlerdendir. Çalışmalarda merkezilik ölçütleri derece (degree) ve arasındalık (betweenness) merkeziliği olmak üzere iki farklı şekilde kullanılabilmektedir. Derece merkeziliği ile ağdaki aktörlerin diğer aktörlerle olan bağlantı sayılarının toplamı hesaplanmaktadır. Bağlantı sayısı yüksek olan yani derece merkeziliği yüksek olan aktörler ağda en merkezi konumda bulunmaktadır (Wasserman ve Faust, 1994: 178). Çalı̧̧ma kapsamında ele alınacak olursa derece merkeziliği yüksek olan anahtar sözcüklerin diğer anahtar sözcüklerle bağ sayısı fazla olmakta ve ağ haritasında merkezi konumda bulunmaktadırlar. Örneğin " $\mathrm{A}$ " anahtar sözcügünün derece 
merkeziliğinin yüksek olması "A" anahtar sözcüğünün çoğu çalışmada birçok farklı anahtar sözcükle birlikte ele alındığı anlamını taşımaktadır.

Arasındalık merkeziliği ise bir aktörün birbiriyle bağlantısı olmayan iki aktör arasında bulunma derecesini göstermektedir. Arasındalık merkeziliği yüksek olan bir aktör birbiriyle bağlantısı olmayan iki aktör arasında bulunarak bağlantıyı sağlamakta ve aracılık yapmaktadır (Wasserman ve Faust, 1994:188). Çalışma kapsamında ele alınacak olursa "B" anahtar sözcüğünün arasındalık merkeziliğinin yüksek olması, ağ haritasında "B" anahtar sözcüğ̈nün birbirleriyle ilişkisi olmayan çok sayıda anahtar sözcügün arasında yer aldığı ve bu anahtar sözcükler arasında köprü görevi üstlendiği anlamına gelmektedir.

Çalışma kapsamında işe angaje olma ile ilişkili 97 makalenin anahtar sözcükleri sosyal ağ analizine tabi tutulmuş ve bu anahtar sözcüklerin oluşturduğu ağ haritası ortaya çıkarılmaya çalışılmıştır. Bu kapsamda, sosyal ağ analiz programı olan UCINET 6'dan yararlanılmıştır. Makalelerden elde edilen 140 adet anahtar sözcük UCINET 6 programında 140 x140'lik matrise dikey ve yatay olarak girilmiştir. Bazı makalelerde aynı kavram için farklı ifadelerin kullanıldığı tespit edilmiştir. Aynı anlama gelen bu ifadelerin matriste ayrı ayrı yer almaması için bu ifadeler veri matrisine tek bir anahtar sözcük olarak girilmiştir. Çalışma kapsamında sağlık sektörünü temsil etmesi dolayısıyla "sağlık sektörü, sağlık hizmetleri, hekim, hemşire, hastane, sağlık çalışanları ve sağlık" anahtar sözcükleri "sağlık sektörü", bankacılık sektörünü temsil etmesi dolayısıyla "bankacilık sektörü, banka çalışanları ve banka" anahtar sözcükleri "bankacılık sektörü", turizm sektörünü temsil etmesi dolayısıyla "turizm, turizm sektörü, konaklama işletmeleri, tur rehberleri, otel endüstrisi ve otel" anahtar sözcükleri turizm sektörü olarak veri matrisine işlenmiştir.

"Organizational engagement" anahtar sözcügünün yerine kullanılan Türkçe çeviri sözcükler olan "kuruma adanmışlık, örgüte tutkunluk, ve örgüte cezbolma" anahtar sözcükleri matrise "örgüte angaje olma", "job, work ve employee engagement" kelimelerinin yerine kullanılan Türkçe çeviri sözcükler olan "işe angaje olma, işle bütünleşme, işe bağllık, işe cezbolma, işe gömülmüşlük, işe adanma, tutkunluk, işe adanmışlık boyutları, işe tutkunluk, dinçlik, adanmışlık, yoğunlaşma, çalışanın işe tutulması, angaje olma, işe gönülden adanma, işe adanmışlık, çalışmaya tutkunluk, bağlılık, işe tutulma, işe sarılma ve işe bağlanma" anahtar sözcükleri matrise "işe angaje olma" olarak kodlanmıştır.

"Performans, iş performansı, bireysel performans ve işgören performansı" anahtar sözcükleri "iş performansı", "IK uygulamaları, insan kaynakları ve İK yönetimi uygulamaları" anahtar sözcükleri "IK uygulamaları", "iş etiği, ahlak, etik, etik ikilem, çalışma ahlakı ve ahlaki sıkıntı" anahtar sözcükleri "iş etiği", "örgütsel destek, algilanan örgütsel destek ve örgütsel destek alg1sı" anahtar sözcükleri örgütsel destek, "örgütsel adalet, örgütsel adalet algıSı ve dağıtımsal adalet" anahtar sözcükleri örgütsel adalet, "örgütsel vatandaşlık davranışı ve örgütsel vatandaşlık" örgütsel vatandaşlık olarak kodlanmıştır. "Tükenmişlik, duygusal tükenmişlik ve tükenmişlik sendromu" anahtar sözcükleri "tükenmişlik", "beş faktör kişilik ve kişilik" anahtar sözcükleri "kişilik", "algılanan stres ve stres" anahtar sözcükleri "stres", "işe angaje olma ölçeği, UWES 9, UWES 3, UWES 6, işe tutulma ölçeği, Utrecht işe angaje olma ölçeği ve ultra kısa işe angaje olma ölçeği" anahtar sözcükleri "işe angaje olma ölçeği" olarak kodlanmıştır. "Yapı geçerliliği, yakınsak geçerlilik, rraksak geçerlilik ve geçerlilik" anahtar sözcükleri "geçerlilik analizi", "güvenilirlik ve güvenilirlik analizi" anahtar sözcükleri "güvenilirlik analizi", "iş yaşamında mutluluk ve mutluluk" anahtar sözcükleri "mutluluk”, “dönüşümcü liderlik ve dönüşümsel liderlik” anahtar sözcükleri “dönüşümcü liderlik”, "yönetici desteği ve algılanan yönetici desteği" anahtar sözcükleri "yönetici desteği" olarak kodlanmıştır.

"İş aile iş çatışması ve iş aile çatışması" anahtar sözcükleri "iş aile çatışması", "yaşam kalitesi ve iş yaşam kalitesi" anahtar sözcükleri "iş yaşam kalitesi", "örgütsel sinizm ve sinizm" anahtar sözcükleri "örgütsel sinizm", "kişi iş uyumu ve birey örgüt uyumu" anahtar sözcükleri birey örgüt uyumu ve "iş zanaatkarlığ ve zanaatkar" anahtar sözcükleri "zanaatkar" olarak veri matrisine işlenmiştir. "Pozitif örgütsel davranış ve pozitif örgütsel davanmış değişkenleri” anahtar sözcükleri "pozitif örgütsel davranış", "öznel iyi oluş ve öznel iyi olma" anahtar sözcükleri "öznel iyi oluş", "yenilikçilik ve inovasyon" anahtar sözcükleri "yenilikçilik", "algılanan örgütsel destek ve örgütsel destek" anahtar sözcükleri "örgütsel destek", "aracllık etkisi ve aracıllk rolü" anahtar sözcükleri "aracılık etkisi", "proaktif çalı̧̧ma davranışı ve proaktif davanış" anahtar sözcükleri "proaktif davranış", "işin özellikleri ve iş özellikleri" anahtar sözcükleri "iş özellikleri" olarak kodlanmıştır. Yapısal ve psikolojik güçlendirme kavramları güçlendirmenin iki türü olması sebebiyle "yapısal güçlendirme, psikolojik güçlendirme ve güçlendirme" anahtar sözcükleri de "güçlendirme" olarak veri matrisine 
işlenmiştir. "Genel öz yeterlilik ve öz yeterlilik" yerine "özyeterlilik", “örgütle özdeşleşme ve örgütsel özdeşleşme" yerine "örgütsel özdeşleşme" ve "örgüte bağlllık, örgütsel bağll1ık" yerine "örgütsel bağlllık" anahtar sözcükleri kodlanmıştır. Aynı makale içerisinde kullanılan "Kültür ve örgüt kültürü" anahtar kelimeleri yerine "örgüt kültürü" ve "karizma ve liderlik karizması" yerine ise "liderlik karizması" veri matrisine işlenmiştir. Anahtar sözcükler arasındaki bağlantılar, anahtar sözcüklerin aynı makalede birlikte yer alıp almamalarına göre kodlanmıştır. Örneğin aynı makalede "örgüt kültürü" ve "işe angaje olma" anahtar sözcükleri birlikte kullanıldığında, veri matrisinde iki anahtar sözcügün kesiştiği bölgeler "1" olarak kodlanmıştır. Aynı makalede birlikte kullanılmayan anahtar sözcüklerin kesişim bölgesi ise " 0 " olarak kodlanmıştır. Örneğin çalışma kapsamında ele alınan 97 makalede "örgütsel bağlılık" ve "babacan liderlik" anahtar sözcüklerinin birlikte ele alınmadığı tespit edilerek veri matrisine iki anahtar sözcüğün kesişim bölgelerine " 0 " kodlanmıştır. Kodlama öncelikle bir excel tablosuna yapılmış olup sonrasında UCINET 6 programında kullanılmıştır. Bu program vasıtasıyla görsel ağ haritası çıkarılmıştır.

\section{BULGULAR}

Çalışmada "job/ employee/ work engagement" anahtar sözcükleri taratılarak yönetim ve organizasyon alanında 10.06.2020 tarihine kadar yayınlanmış olan 97 adet yerel makaleye ulaşılmıştır. Ulaşılan makaleler, yayınlandıkları "yıllar" itibariyle sınıflandırılmış olup ulaşılan bulgular aşağıda Tablo 1'de gösterilmiştir.

Tablo 1: Makalelerin Yayınlandıkları "Yıllar" İtibariyle Tasnifi

\begin{tabular}{|l|l|}
\hline Yillar & Makale Sayıs \\
\hline 2011 & 2 \\
\hline 2013 & 3 \\
\hline 2014 & 3 \\
\hline 2015 & 6 \\
\hline 2016 & 6 \\
\hline 2017 & 12 \\
\hline 2018 & 20 \\
\hline 2019 & 40 \\
\hline 10.06 .2020 itibariyle 2020 & 5 \\
\hline Toplam & 97 \\
\hline
\end{tabular}

Tablo 1'de elde edilen bulgulardan yol çıkılarak yerel yazında işe angaje olmaya ilişkin çalışmaların 2011 yılı itibariyle başladığı söylenebilir. 2011 yılında iki makalede ele alınan işe angaje olma kavramının yıllar ilerledikçe daha çok çalışmada ele alındığı gözlemlenmektedir. 2009- 2016 yılları arasında yayınlamış makale sayıları incelendiğinde yıllar itibariyle makale sayısındaki artışın yavaş olduğu görülmektedir. 2017 yılından sonra ise bu artışın daha yoğun yaşandığı gözlemlenmektedir. Bu bulgudan yola çıkılarak 2017 yılından sonra konuya ilişkin ilginin arttığı söylenebilmektedir. Konuyu olan ilginin en yoğun yaşandığı yıl ise 2019'dur. En fazla sayıda makale 2019 yılında yayınlamıştır.

Çalışma kapsamında, ulaşılan doksan yedi makalede "work/ job /employee engagement" kavramları yerine hangi çeviri sözcüklerin kullanıldığı araştırılmıştır. Bu amaçla makalelerde yer alan İngilizce anahtar sözcükler (Keywords) ile Türkçe anahtar sözcükler karşılaştırılmış ve "work/ job /employee engagement" anahtar sözcükleri yerine kullanılan Türkçe çeviri sözcükler kayıt altına alınmıştır. Aşağıda yer alan tablo 2' de çeviri sözcükler, bu sözcüklerin anahtar sözcük olarak geçtiği makaleler ve makale sayıları gösterilmektedir. 
Tablo 2: "Work/ job /employee engagement” Anahtar Sözcükleri Yerine Kullanılan Türkçe Çeviri Sözcükler

\begin{tabular}{|c|c|c|}
\hline $\begin{array}{l}\text { "Work/ Job/ } \\
\text { Employee } \\
\text { Engagement" } \\
\text { Yerine } \\
\text { Kullanılan } \\
\text { Türkçe Çeviri } \\
\text { Sözcükler }\end{array}$ & İlgili Kaynaklar & $\begin{array}{l}\text { Makale } \\
\text { Sayısı }\end{array}$ \\
\hline $\begin{array}{l}\text { Çalışmaya } \\
\text { Tutkunluk }\end{array}$ & $\begin{array}{l}\text { Acaray, 2019a, 2019b; Arıkan ve Çankır, 2019; Başaran, 2017; Bekmezci ve } \\
\text { Yıldız, 2019; Boz, 2019; Çalışkan, 2014; Çankır ve Şahin, 2018; Çankır, 2016; } \\
\text { Örücü ve Hatipoğlu, 2018; Özer Topaloğlu vd., 2019; Öztürk Anabal ve } \\
\text { Arıkan, 2019; Polat vd., 2018; Şahin ve Çankır, 2018, 2019; Şahin vd.,2018; } \\
\text { Turgut, 2013, 2011; Zor ve Özsoy, } 2019 .\end{array}$ & 19 \\
\hline İşe Tutkunluk & $\begin{array}{l}\text { Aşçı ve Taşçıŏlu Baysal, 2019; Atilla ve Yıldırım 2019; Başoda, 2017; Bektaş } \\
\text { ve Karagöz, 2018; Bolelli, 2019; Dede vd., 2014; Demir Harputoğlu ve } \\
\text { Dönmez Polat, 2017; Erkal, 2019; Kaplanseren ve Örücü, 2018; Örücü ve } \\
\text { Uçku, 2019; Özaralli, 2017; Seçkin, 2018; Şen, } 2019 .\end{array}$ & 13 \\
\hline $\begin{array}{l}\text { Çalışanın İşe } \\
\text { Tutulması }\end{array}$ & Asar, 2018. & 1 \\
\hline İşe Tutulma & Güler vd., 2019; Güler ve Ocak, 2019; Güler, 2019; Ocak, 2019. & 4 \\
\hline İşe Adanmışlık & $\begin{array}{l}\text { Akçakanat vd., 2019; Akın, 2019; Anafarta ve Yılmaz, 2019; Aslan, 2020; } \\
\text { Aybas ve Kosa, 2018; Aydemir ve Endirlik, 2019; Aydemir, 2018; Bağcığlu } \\
\text { ve Kaygın, 2018; Bayram, 2019; Büyükbeşe ve Gökaslan, 2018; Coşkuner ve } \\
\text { Şentürk, 2017; Erdirençelebi ve Karataş, 2019; Gülen Ertosun vd., 2018; } \\
\text { İnce, 2016; Işı ve Kama, 2018; Keleş, 2014; Kılıç vd., 2020; Maden Eyiusta, } \\
\text { 2015; Özyilmaz ve Süner, 2015; Özeren vd., 2019; Öztürk Çiftçi, 2019; } \\
\text { Şahinbaş ve Erigüç, 2019; Turan ve Özdemir, 2019; Ulukök vd., 2017; Uysal } \\
\text { vd., 2018; Yener, 2019. }\end{array}$ & 26 \\
\hline İşe Adanma & $\begin{array}{l}\text { Baykal, 2019; Bostanc1 ve Ekiyor, 2015; Gürlek ve Tuna, 2019; Gürlek, 2020; } \\
\text { Kanten ve Yeşiltaş, 2013; Kayar ve Erdem, 2017, Ülbeği vd., 2018; Yeşil ve } \\
\text { Mavi, } 2018 .\end{array}$ & 8 \\
\hline $\begin{array}{l}\text { İşe Gönülden } \\
\text { Adanma }\end{array}$ & Uncuoğlu Yolcu ve Çakmak, 2017. & 1 \\
\hline $\begin{array}{l}\text { İşle } \\
\text { Bütünleşme }\end{array}$ & $\begin{array}{l}\text { Akşit Aşık, 2016; Deniz ve Yıldırım, 2020; Kartal vd., 2015; Öngöre, 2019, } \\
\text { 2013; Vatansever Durmaz, } 2019 .\end{array}$ & 6 \\
\hline $\begin{array}{l}\text { İşe Angaje } \\
\text { Olma }\end{array}$ & $\begin{array}{l}\text { Arslan ve Demir, 2017; Bilginoğlu ve Yozgat, 2019; Çelik Ağırman ve } \\
\text { Naktiyok, 2018; Güzel ve Uyar, 2019; Kodaş, 2018; Özkalp ve Meydan, } \\
2015 .\end{array}$ & 6 \\
\hline $\begin{array}{l}\text { İşe } \\
\text { Gömülmüşlük }\end{array}$ & Kanten vd., 2016; Kesen ve Akyüz, 2016. & 2 \\
\hline İşe Cezbolma & Eroğluer ve Kahraman, 2019; Esen, 2011; Karagonlar vd., 2015; Kartal, 2017 & 4 \\
\hline İşe Bağlılık & Gül ve Erol, 2016; İnce ve Bozkurt, 2019; Özgüleş, 2019; Yıldız vd., 2017. & 4 \\
\hline İşe Bağlanma & İnce ve Topcu, 2017; Kerse ve Karabey, 2019; Koçak, 2020. & 3 \\
\hline Toplam & & 97 \\
\hline
\end{tabular}

Tablo 2 incelendiğinde, alan yazındaki çalışmalarda "work/ job /employee engagement" anahtar sözcüklerinin Türkçe'ye çoğunlukla "işe adanmışlık" olarak çevrildiği, "işe adanmışlık" anahtar sözcügünü takiben ise "çalışmaya tutkunluk" ve "işe tutkunluk" çeviri kelimelerinin sıklıkla kullanıldığı gözlemlenmektedir. "İşe gönülden adanma, işe gömülmüşlük, işe cezbolma, işe bağlılık ve işe bağlanma" ise nadiren kullanılan çeviri sözcüklerdir. Genellikle yazında "work/ job commitment" kelimelerinin çevirisi olarak kullanılan "işe bağlılık/ bağlanma" çeviri sözcüklerinin bazı yazarlar tarafından "work/ job /employee engagement" kavramlarının çevirisinde de kullanıldığı gözlemlenmiştir. 
Çalışma kapsamında sosyal ağ analizi kullanılarak alan yazındaki işe angaje olma makalelerinin anahtar sözcüklerinin ağ yapısı ortaya çıkarılmaya amaçlanmıştır. Bu amaçla işe angaje olma ile ilişkili 97 makalenin 140 anahtar sözcügü $140 \times 140$ 'lük veri matrisine işlenerek sosyal ağ analizine tabi tutulmuştur. Anahtar sözcüklere ilişkin derece ve arasındalık merkeziliği bulguları aşağıda Tablo 3'de yer almaktadır:

Tablo 3. Yönetim ve Organizasyon Makalelerindeki Anahtar Sözcüklerin Merkezilik Ölçütleri*

\begin{tabular}{|l|c|c|}
\hline Anahtar Sözcükler & Derece Merkeziliğ & Arasındalık Merkeziliğ \\
\hline İşe Angaje Olma & 136,000 & 17325.412 \\
\hline İşten Ayrılma Niyeti & 29,000 & 423.785 \\
\hline İş Tatmini & 19,000 & 188.409 \\
\hline İş Performansı & 18,000 & 122.230 \\
\hline Turizm Sektörü & 15,000 & 73.083 \\
\hline Duygusal Emek & 12,000 & 40.083 \\
\hline Aracılık Etkisi & 11,000 & 32.627 \\
\hline Örgütsel Adalet & 10,000 & 22.456 \\
\hline Örgütsel Destek & 10,000 & 26.000 \\
\hline Yönetici Desteği & 10,000 & 26.667 \\
\hline Pozitif Örgütsel Davranış & 9,000 & 22.167 \\
\hline Sağlık Sektörü & 9,000 & 22.075 \\
\hline Pozitif Psikolojik Sermaye & 9,000 & 18.833 \\
\hline İş- Aile Çatışması & 9,000 & 18.467 \\
\hline Örgüte Angaje Olma & 8,000 & 15.552 \\
\hline Örgütsel Özdeşleşme & 8,000 & 12.511 \\
\hline İnsan Kaynakları Uygulaması & 8,000 & 19.350 \\
\hline Güçlendirme & 8,000 & 14.333 \\
\hline Öz Yeterlilik & 7,000 & 13.186 \\
\hline Örgütsel Sinizm & 7,000 & 8.000 \\
\hline Pozitif Psikoloji & 6,000 & 6.333 \\
\hline Stres & 6,000 & 3.056 \\
\hline Mutluluk & 6,000 & 6.000 \\
\hline Liderlik Karizması & 6,000 & 6.000 \\
\hline Örgütsel Vatandaşlık & 6,000 & 7.167 \\
\hline Geçerlik Analizi & 6,000 & 171.303 \\
\hline Güvenilirlik Analizi & 6,000 & 171.303 \\
\hline İş Yükü & 6,000 & 5.333 \\
\hline Birey- Örgüt Uyumu & 6,000 & 7.667 \\
\hline Bankacilık Sektörü & 6,000 & 5.758 \\
\hline & & \\
\hline
\end{tabular}

*Tablonun çok uzun olmaması amacıyla derece merkeziliği 6,000'dan küçük olan anahtar sözcükler tabloya dahil edilmemiştir.

Tablo 3 incelendiğinde, en yüksek derece merkeziliği ve arasındalık merkeziliğine sahip kavramın "işe angaje olma" olduğu gözlemlenmektedir. "İşe angaje olma" anahtar sözcügünü takiben sırasıyla "işten ayrılma niyeti", "iş tatmini", "iş performansı" ve "turizm sektörü" anahtar sözcükleri en yüksek derece merkeziliğine sahiptir. Bu anahtar sözcükler en yüksek bağlantı sayısına sahip yani ağda en çok odaklanılan ve çok sayıda makalede ele alınan kavramlardır. "İse angaje olma", "işten ayrılma niyeti", "iş tatmini", "geçerlik analizi", "güvenilirlik analizi" ve "iş performansı" kavramlarının ise yüksek arasındalık merkeziliğine sahip olduğu gözlemlenmektedir. Arasındalık merkeziliği yüksek olan kavramlar birbirleriyle ilişkisi olmayan kavramları köprü görevi görerek birbirleriyle ilişkilendirmektedir. "Geçerlik analizi" ve "güvenilirlik analizi" anahtar sözcüklerinin arasındalık merkezilik değerlerinin derece merkeziliği değerlerine kıyasla oldukça yüksek olduğu gözlemlenmektedir. Geçerlik ve güvenilirlik analizleri anahtar sözcüklerinin makalelerde sıklıkla kullanılmamalarına rağmen bu kavramların birbirleriyle ilişkili olmayan kavramları yüksek bir oranda bir araya getirdiği söylenebilmektedir. 
Alan yazında yer alan işe angaje olma makalelerinin oluşturduğu ağ haritası Şekil 1'de gösterilmektedir.

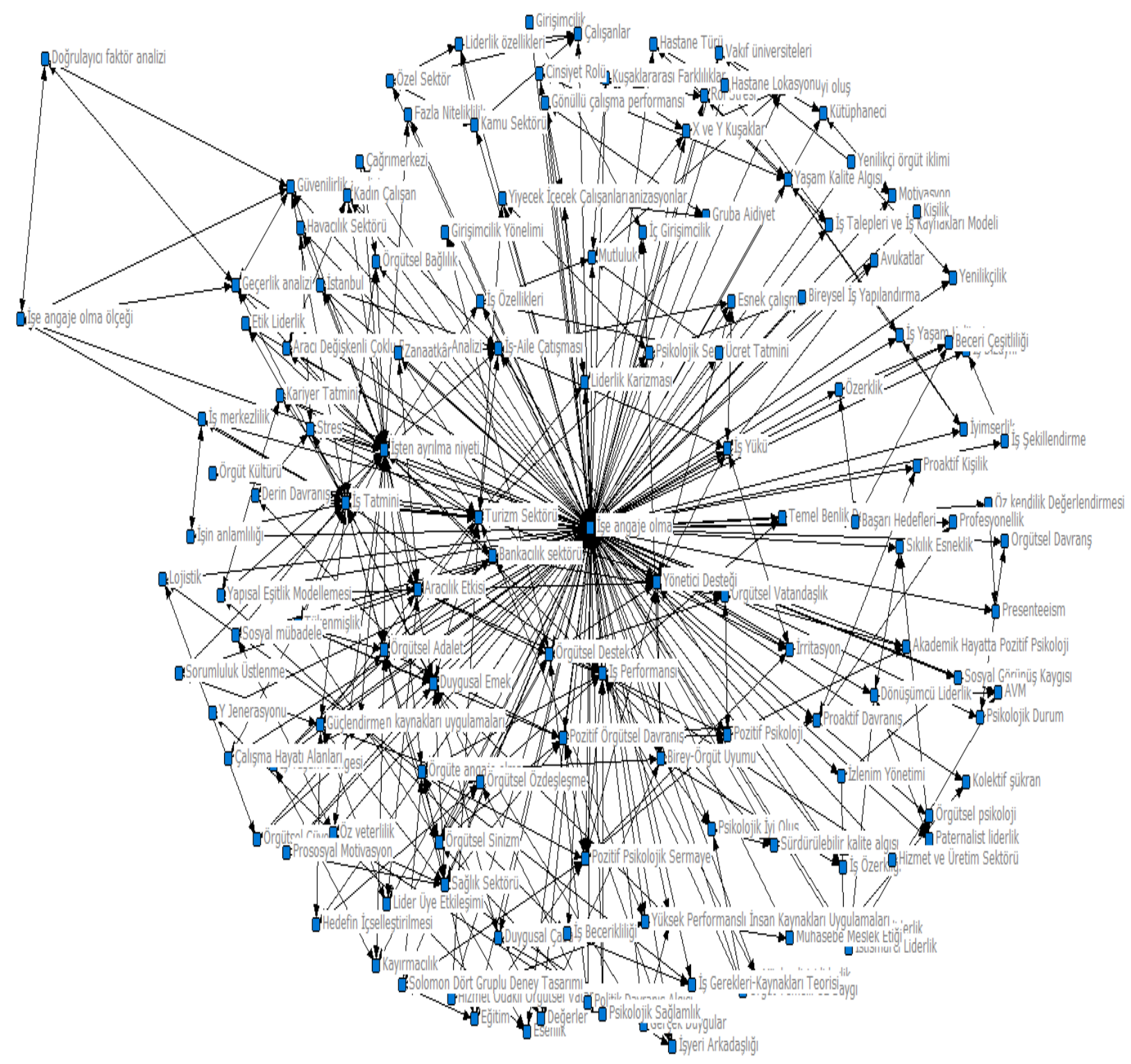

Şekil 1: Yerel Yazındaki “İşe Angaje Olma” Makalelerinin Ağ Haritası

\section{SONUÇ ve TARTIŞMA}

Bibliyometrik bir araştırma niteliği taşıyan bu çalışmada, yönetim ve organizasyon alanındaki 97 adet işe angaje olma makalesi ele alınmış ve yerel yazına ilişkin genel bir değerlendirme yapılması amaçlanmıştır.

Uluslararası yazında, 1990 yılında Kahn'ın çalışmasında işe angaje olma kavramının ortaya atılmasıyla birlikte işe angaje olmaya ilişkin araştırmalar yapılmaya başlanmıştır. Yerel yazında ise angaje olmaya ilişkin ilk çalışma 2009 (Ardıç ve Polatcı, 2009) yılında yapılmış olup, işe angaje olmaya ilişkin ilk çalışma 2011 (Turgut, 2011) yılında yapılmıştır. Yerel yazında işe angaje olmaya ilişkin ilk çalışmanın Kahn'ın çalışmasından yaklaşık 21 yıl sonra yapılması işe angaje olma olgusunun yerel yazına geç girdiğini göstermektedir. Yerel yazında yıllar itibariyle yapılan çalışmalar karşılaştırıldığında ise işe angaje olmaya ilişkin çalışmaların 2017 yılından sonra artış gösterdiği ve en fazla sayıda çalışmanın 2019 yılında yapıldığı gözlemlenmektedir. Bu kapsamda yerel yazında konuya olan ilginin son yıllarda arttığı ve yerel yazının uluslararası yazından daha yavaş bir ilerleme gösterdiği söylenebilmektedir. Ayrıca, işe angaje olma olgusunun, uluslararası yazında yaklaşık 21 yıldır çalışılmasına rağmen hala araştırmacılar tarafından sıklıkla incelendiği ve birçok farklı kavramla birlikte ele alınarak çalışılmaya devam edildiği gözlemlenmektedir. Yerel yazında ise son yıllarda 
popülerlik kazanan olguya olan ilginin devam edeceği ve hem yerel yazında hem de yabancı yazında olgu üzerinde ilerleyen yıllarda da araştırma yapılacağı tahmin edilmektedir.

Uluslararası yazında "work/job/employee engagemet" olarak kullanılan ve bu makale kapsamında da işe angaje olma olarak ele alınan kavramın Türkçe'ye birçok çeviri sözcükle geçtiği söylenebilmektedir. Ancak makalelerde yoğun olarak "işe adanmışlık" çeviri sözcüğünün kullanıldığı gözlemlenmektedir. Makalelerde "işe adanmışlık" dışında 12 çeviri sözcüğün daha kullanılmasının yerel yazında bir anlam karmaşasına sebep olabileceği tahmin edilmektedir. Çoğunlukla "work/ job commitment" sözcüklerinin çevirisi olarak kullanılan "işe bağlllık ve işe bağlanma" sözcüklerinin aynı zamanda "work/job/employee engagemet" kelimelerinin çevirisi için kullanılması bu düşünceyi destekler niteliktedir.

Çalı̧̧ma kapsamında, makalelerin anahtar sözcüklerden yola çıkılarak sosyal ağ analizi yapılmıştır. Sosyal ağ analizi ile elde edilen bulgular neticesinde ise en yüksek derece merkeziliği olan kavram "işe angaje olma" olgusudur. Bu çalışma kapsamında işe angaje olma makalelerine odaklanılmış olması ve her çalışmada işe angaje olma anahtar sözcüğünün aranması nedeniyle bu bulgu beklenen bir bulgudur. "İşe angaje olma" olgusundan sonra "işten ayrılma niyeti", "iş tatmini", "iş performansı" ve "turizm sektörü" olgularının derece merkeziliklerinin yüksek olduğu gözlemlenmiştir. İşe angaje olma kavramı sıklıkla "işten ayrılma niyeti", "iş tatmini" ve "iş performansı" ile birlikte çalışılmıştır. Yabancı yazın incelendiğinde de "işten ayrılma niyeti", "iş tatmini" ve "iş performansı" kavramlarının sıklıkla "işe angaje olma" ile birlikte ele alındığı gözlemlenmiştir. Ayrıca, çalışmaların çoğunlukla turizm sektörü çalışanlarına odaklandığı söylenebilmektedir. Yazına göre, farklı sektörlerde faaliyet gösteren birçok işletme için işe angaje olma olgusu önemli bir konu olarak görülmektedir. Çalışanların işe angaje olmaları işletmelerin rekabette öne geçmelerinde önemli bir rol oynamakta ve işe angaje olan çalışanlar işletmelere birçok açıdan fayda sağlamaktadır. Bu kapsamda yerel yazında işe angaje olma olgusuna ilişkin çalışmaların çoğunlukla turizm sektörü çalışanları üzerine yapıldığının tespit edilmesi ilgi çekici bir bulgudur.

Uluslararası yazın incelendiğinde, Maslach ve Leiter (2008)'in çalışmalarında işe angaje olma kavramını tükenmişliğin zıttı olarak tanımlamalarından ötürü çok sayıda çalışmanın işe angaje olma ile tükenmişlik olgularını birlikte ele aldığı gözlemlenmektedir. Yerel yazın incelendiğinde ise kısıtlı sayıda çalışmanın (Güzel ve Uyar, 2019; Çalışkan, 2014; Yeşil ve Mavi, 2018) bu iki kavram arasındaki ilişkiyi ele aldığı gözlemlenmiştir. $\mathrm{Bu}$ kapsamda yerel yazında işe angaje olma makalelerinin tükenmişlik üzerine odaklanmadığ 1 söylenebilmektedir.

Yabancı yazın incelendiğinde "işe angaje olma" olgusunun "iş becerikliliği (job crafting)" (Bakker vd., 2012; Lu vd., 2014; Demerouti vd., 2015; Shin vd., 2020) ve "psikolojik sözleşme" (Rayton ve Yalabik, 2014; Bal vd., 2013; Parzefall ve Hakanen 2010) olguları ile birlikte sıklıkla ele alındığı gözlemlenmektedir. Yerel yazında ise "iş becerikliliği" ile "işe angaje olma" olgularını birlikte ele alan herhangi bir çalışmaya rastlanmamış ve "psikolojik sözleşme" ve "işe angaje olma" ilişkisini inceleyen ise sadece bir çalışmaya (Başaran, 2017) rastlanmıştır. Yabancı yazında "iş becerikliliği" ve "psikolojik sözleşme" kavramlarının "işe angaje olma" olgusu ile sıklıkla ele alınmalarına rağmen yerel yazında bu kavramların aynı ilgiyi görmemesi dikkat çekmektedir. Ayrıca yabancı yazında son yıllarda "işe angaje olma" kavramının "işin anlamlılığı (work meaningfulness)" (Afsar vd., 2020; Han vd., 2020; Oprea vd., 2020) ve "kurumsal sosyal sorumluluk" (Chaudhary, 2019; Gupta, 2015; Godkin 2014) kavramları ile birlikte çalışılmaya başlandığı gözlemlenmektedir Yerel yazında ise "işin anlamlılığı" ile "işe angaje olma" kavramlarını birlikte ele alan bir çalışmaya (Seçkin, 2018) rastlanmış ve "kurumsal sosyal sorumluluk" ile "işe angaje olma" kavramlarını birlikte ele alan herhangi bir çalışmaya rastlanmamıştır. İlerleyen yıllarda hem yerel hem de yabancı yazında bu olguların "işe angaje olma" olgusuyla ilişkisini inceleyen daha çok çalışmanın olacağı tahmin edilmektedir.

Sosyal ağ analizi ile elde edilen diğer bulgular arasındalık merkeziliğine ilişkin bulgulardır. Çalışma kapsamında en yüksek arasındalık merkeziliğine sahip olgu "işe angaje olma" olgusudur. Yani birbirleriyle ilişkisi olmayan kavramların arasında köprü görevi görmektedir. İşe angaje olma olgusu ele alınan her makalede geçtiği için arasındalık merkeziliğinin en yüksek olması şaşırtıcı değildir. İşe angaje olma olgusunu takiben "işten ayrılma niyeti", "iş tatmini", "geçerlik analizi", "güvenilirlik analizi" ve "iş performansı" kavramlarının yüksek arasındalık merkeziliğine sahip olduğu gözlemlenmektedir. Bu bulgudan yola çıkılarak, bu olguların farklı makalelerde birçok farklı ve birbirleriyle ilişkisi olmayan olgularla birlikte ele alındığı söylenebilmektedir. Yani bu olgular hep aynı olgularla birlikte ele alınarak çalışılmamıştır. Örneğin 
iş tatmini olgusu örgütsel adalet, özdeşleşme, işten ayrılma niyeti, örgüt kültürü, güçlendirme gibi birbirleriyle ilgisi olmayan farklı olgularla birlikte ele alınmıştır. Olguların araştırmacılar tarafından farklı olgularla ele alınarak çalışılması alan yazının zenginleşmesine yol açmaktadır. Bu kapsamda yerel işe angaje olma makalelerinde, arasındalık merkeziliği yüksek olan olgulara rastlanmış olması alanın gelişimi açısından önemli bulunmaktadır. Aynı olguların sürekli olarak birbirleriyle çalışılmadığını gösteren bu bulgu alan yazında yeni bulguların ortaya çıkışına sebep olabilmektedir.

Bu çalışma, son yıllarda yoğun ilgi gören işe angaje olma olgusunun hangi konularla yoğun bir şekilde ilişkilendirildiğini veya ilişkilendirilmediğini göstermesi açısından bu konuda çalışmak isteyen araştırmacılara yol gösterici niteliktedir. Bu çalışma vasıtasıyla araştırmacılar üzerinde çok odaklanılmayan konular üzerine odaklanarak özgün araştırma soruları oluşturabilir ve alan yazına katkı sağlayabilirler. Ayrıca bu çalışma vasıtasıyla işe angaje olma kavramının hangi kavramlarla ilişkilendirildiğinin ortaya çıması işletmeler açısından da önem taşıyabilmektedir. İşe angaje olan bireyleri işe almak veya çalıştırmak isteyen insan kaynakları müdürleri veya yöneticiler yerel yazındaki birçok makaleyi araştırmak yerine bibliyometrik nitelikteki bu çalışma ile bütünsel bir şekilde işe angaje olmanın hangi kavramlarla ilişkilendirildiğini görebilir ve çalışanlarının işe angaje olmalarını arttıracak araçlar bulabilirler.

\section{Kaynakça}

Acaray, A. (2019). Öz Kendilik Değerlendirmesinin Presenteeism Üzerinde Etkisinde Çalışmaya Tutkunluğun Aracilık Rolü, Işletme Araştırmaları Dergisi, 11(2), 890- 904.

Saks, A.M. (2006). Antecedents and consequences of employee engagement, Journal of Managerial Psychology, 21(7), 600-619.

Schaufeli, W.B., Salanova, M., González-Romá, V. and Bakker, A. B. (2002). The measurement of engagement and burnout: A two sample confirmatory factor analytic approach, Journal of Happiness Studies, 3, 71-92.

Acaray, A. (2019). Örgüt Temelli Özsaygının İş Performansına Etkisinde Psikolojik İyi Oluş ve Çalışmaya Tutkunluğun Aracılık Rolü, Business and Economics Research Journal, 10(3), 735- 748.

Akçakanat T., Uzunbacak H.H. ve Acar O. K. (2019). İnsan Kaynakları Yöneticilerinin İş Becerikliliklerinin İşe Adanmışlıkları Üzerine Etkisi, OPUS Uluslararası Toplum Araştırmaları Dergisi, 10(17), 395- 419.

Akın Ö. (2019). İş özellikleri ve işe adanmışlığın çalışanın işten ayrılma niyeti üzerindeki etkisi, Journal of Politics, Economy and Management, 2(2), 1-18.

Akşit Aşık N. (2016). Örgütsel Adaletin İşle Bütünleşme Üzerindeki Etkisi: Otel İşletmelerinde Bir Uygulama, International Journal of Social Science, 49, 87- 97.

Anafarta A. ve Yılmaz Ö. (2019). Kariyer Tatmini ve İşten Ayrılma Niyeti Arasındaki İlişkide İşe Adanmışlığın Aracılık Rolü, İşletme Araştırmaları Dergisi, 11(4), 2944-2959.

Ardıç K. ve Polatcı S. (2009). Tükenmişlik Sendromu Ve Madalyonun Öbür Yüzü: İşle Bütünleşme. Erciyes Üniversitesi İktisadi ve İdari Bilimler Dergisi, 32, 21-46.

Arıkan S. ve Çankır B. (2019). Gıda ve Finans Sektöründe Çalışan Performansı Hangi Faktörlerden Etkileniyor? Sürdürülebilir Kalite Algısı, Psikolojik İyi Oluş ve Çalışmaya Tutkunluk Değişkenlerinin Rolü, OPUS Uluslararası Toplum Araştırmaları Dergisi, 12(18), 462- 483.

Arslan E. T. ve Demir H. (2017). İşe Angaje Olma ve İş Tatmini Arasındaki İlişki: Hekim ve Hemşireler Üzerine Nicel Bir Araştırma, Yönetim ve Ekonomi, 24(2), 371-389.

Asar R. (2018). Çalışanın İşe Tutulması, Ç.Ü. Sosyal Bilimler Enstitüsü Dergisi, 27(2). 33- 43.

Aslan H. (2020). Dağıtım Adaletinin İş Tatmini Üzerindeki Etkisinde İşe Adanmışlı̆̆ın Aracı Rolü, Üçüncü Sektör Sosyal Ekonomi Dergisi, 55(1), 196- 210.

Aşçı K. ve Taşçıŏlu Baysal H. (2019). Satış Pazarlama Çalışanlarının İşe Tutkunluk Davranışlarının İncelenmesi Üzerine Bir Araştırma, Bucak İşletme Fakültesi Dergisi, 2(1), 35- 53.

Atilla G. ve Yıldırım G. (2019). Öznel İyi Oluş Halinin İşe Tutkunluğa Etkisi: Sinop İli Tekstil Sektörü Örneği, Kırklareli Üniversitesi Iktisadi ve Idari Bilimler Fakültesi Dergisi, 8(2), 188-205. 
Aybas M. ve Kosa G. (2018). Duygusal Emeğin Mesleki Stres ve İşe Adanmışlık Üzerindeki Etkisi: Tur Rehberleri Üzerinde Bir Araştırma, Anemon Muş Alparslan Üniversitesi Sosyal Bilimler Dergisi,6, ICEESS' 18, 103- 111.

Aydemir C. ve Endirlik H. (2019). İşe Adanmışlı̆̆ın Bazı Demografik Değişkenler Açısından İncelenmesi: Bankacılık Sektöründe Bir Araştırma. Atatürk Üniversitesi Sosyal Bilimler Enstitüsü Dergisi, 23 (3) , 10931107.

Afsar B., Ghazali B.A., Umrani W. (2020). Corporate Social Responsibility, Work Meaningfulness and Employee Engagement: The Joint Moderating Effects of Incremental Moral Belief and Moral Identity Centrality, Corporate Social Responsibility and Environmental Management, 27(3), 1264-1278.

Bağcığlu D. ve Kaygın H. (2018). Çalışanların Öz Yeterliliklerinin ve Esenlik Algılarının İşe Adanmışlıklarına Etkisi: İlaç Sektörü Örneği, Kahramanmaraş Sütçü İmam Üniversitesi Sosyal Bilimler Dergisi, 15(2), 607- 626.

Bakker, A.B., Albrecht, S.L., ve Leiter, M.P. (2011). Key Questions Regarding Work Engagement, European Journal of Work and Organizational Psychology, 20(1), 4-28.

Bakker, A. B. ve Bal, P. M. (2010). Weekly work engagement and performance: A study among starting teachers, Journal of Occupational and Organizational Psychology, 83, 189-206.

Bakker, A.B. ve Demerouti E. (2008). Towards a Model of Work Engagement, Career Development International, 13(3), 209-223.

Bal, P.M., de Cooman, R., ve Mol, S.T. (2013). Dynamics of Psychological Contracts With Work Engagement and Turnover Intention: The Influence of Organizational Tenure, European Journal of Work and Organizational Psychology, 22, 107-122.

Bal, P.M., Kooij, D.T.A.M. and De Jong, S.B. (2013). How do Developmental and Accommodative HRM Enhance Employee Engagement and Commitment? The Role of Psychological Contract and SOC Strategies, Journal of Management Studies, 50,545-572.

Başaran R. (2017). Örgütsel Tutum Ve Davranışların İş Performansı ve İşten Ayrılma Niyetine Etkisi: İlişkisel Psikolojik Sözleşmelerin Aracılık Rolü, Iğdır Üniversitesi Sosyal Bilimler Dergisi, 12, 239-270.

Başoda A. (2017). İşe Tutkunluk: Kavramsal Açıdan Bir İnceleme, Uluslararası Tarih ve Sosyal Araştırmalar Dergisi, 17, 71- 98.

Baykal E. (2019). Yenilikçi Örgüt İklimi: İşe Adanma Üzerine Etkisi, Ekonomi, İşletme ve Maliye Araştırmaları Dergisi, 1(3), 266- 279.

Bayram A.(2019). Örgütsel Özdeşleşmenin İş Tatmini Üzerine Etkisinde İşe Adanmışlığın Aracı Rolünün Belirlenmesine Yönelik Bir Araştırma, Anadolu Üniversitesi Sosyal Bilimler Dergisi, 19(4), 321- 334.

Bilginoğlu E. ve Yozgat, U. (2019), Ultra-Kısa İşe Angaje Olma Ölçeği Türkçe Formunun Geçerlilik Ve Güvenilirlik Çalışması, BMIJ, (2019), 7(5): 2863-2872.

Bekmezci M. ve Yıldız B. (2019). Babacan Liderlik İle Çalışmaya Tutkunluk Arasındaki İlişkide Kolektif Şükranın Aracı Etkisi, Hacettepe Üniversitesi Sosyal Bilimler Dergisi, 1(1), $52-73$.

Bektaş M. (2018). İzlenim Yönetimi Davranışının İşe Tutkunluğa Etkisinde Sosyal Görünüş Kaygısının Aracılık Rolü, Sosyal Araştırmalar ve Davranış Bilimleri Dergisi, 4(6), 275- 299.

Bolelli M. (2019). İşe Tutkunluk İle Öznel İyi Olma İlişkisinde Kuşakların Etkilerinin İncelenmesi, İstanbul Ticaret Üniversitesi Sosyal Bilimler Dergisi, 35(1), 247- 272.

Bostancı H. (2015). Çalışanların İşe Adanmasının Örgüt İçi Girişimciliğe Etkisinin İncelenmesi: Sağlık Sektöründe Bir Uygulama, Uluslararası Sağlık Yönetimi Ve Stratejileri Araştırma Dergisi, 1(1), 37 - 51.

Boz H. (2019). Algılanan İnsan Kaynakları Yönetimi Uygulamalarının İşten Ayrılma Niyetine Etkisinde Çalışmaya Tutkunluğun Aracılık Rolü: Turizm İş görenleri Üzerine Bir Araştırma, Mehmet Akif Ersoy Üniversitesi İktisadi ve İdari Bilimler Fakültesi Dergisi, 6(2), 300-315.

Broadus R. N. (1987). Toward a Deffiniation of "Bibliometrics", Scientometrics, 12 (5-6): 373-379. 
Büyükbeşe T. ve Gökaslan M. O. (2018). İşe Gömülmüşlük, İşe Adanmışlık ve İşten Ayrılma Niyeti İlişkisi: Bir Alan Çalışması, Mukaddime Dergisi, 9(2), 135-153.

Chaudhary, R. (2019). Corporate Social Responsibility Perceptions and Employee Engagement: Role of Psychological Meaningfulness, Safety and Availability, Corparate Governance, 19, 631-647.

Coşkuner M. ve Şentürk F. K. (2017). Dönüşümcü ve İstismarcı Liderlik Davranışlarının İşe Adanmışlık Üzerine Etkisi: AVM Çalışanları Örneği, ÇAKÜ Sosyal Bilimler Enstitüsü Dergisi, 8(2), 165- 195.

Çalışkan S. C. (2014). Pozitif Örgütsel Davranış Değişkenleri İle Yeni Araştırma Modelleri Geliştirme Arayışları: Pozitif Örgütsel Davranış Değişkenlerinin İşe Adanmışlık, Tükenmişlik ve Sinizm Üzerine Etkileri ve Bu Etkileşimde Örgütsel Adalet Algısının Aracilık Rolü Üzerine Bir Araştırma, Dokuz Eylül Üniversitesi Sosyal Bilimler Enstitüsü Dergisi, 16(3), 363-382.

Çankır B. ve Şahin S. (2018). Medya-Kültür Ve Sanat Alanında Çalışanların Psikolojik İyi-Oluşları İle İşten Ayrılma Niyetleri Arasındaki İlişkide Çalışmaya Tutkunluğun Aracı Rolü, Uluslararası İktisadi ve İdari Incelemeler Dergisi, 7. UíK Özel Sayısı, 333- 346.

Çankır B. (2016). Çalışmaya Tutkunluğun Örgütsel Vatandaşlık Davranışı Üzerine Etkisi Ve Bir Araştırma, Uluslararası Sosyal Araştırmalar Dergisi, 9(47), 766- 771.

Çelik Ağırman Ü. H. ve Naktiyok A. (2018). Psikolojik Sermaye ve Profesyonellik İlişkisinde İşe Angaje Olmanın Düzenleyici Rolü, Atatürk Üniversitesi Sosyal Bilimler Enstitüsü Dergisi, 22 (Özel Sayı): 26652683.

Dede N. P., Yılmaz G. ve Karaca Çakınberk A. (2014). İş-Aile Çatışması Ve İşten Ayrılma Niyeti Arasındaki İlişki Üzerinde İşe Tutkunluğun Aracllı Etkisi, Tunceli Üniversitesi Sosyal Bilimler Dergisi, 2(5), 121-142.

Demir Harputoğlu D. ve Dönmez Polat D. (2017). İşe Tutkunluk Ve İş-Aile-İş̧ Çatışmasının İşten Ayrılma Niyetine Etkisi: Konaklama İşletmelerinde Bir Uygulama, Sosyal Bilimler Dergisi, 4(13), 435-450.

Deniz M. ve Yıldırım M. (2020). İş Yükü Fazlalığı Algısının İşle Bütünleşme Düzeyine Etkisi: Avukatlar Üzerinden Bir Araştırma, Mecmua Uluslararası Sosyal Bilimler Dergisi, 5(9), 199-219.

Erdirençelebi M. ve Karataş C. G. (2019). Örgütsel Adaletin İşe Adanmışlık İle İşten Ayrılma Niyeti Üzerine Etkisi, BMIJ, (2019), 7(4): 1825-1849.

Erkal P. (2019). Girişimciliğin İşe Tutkunluğa Etkisinde Birey- Örgüt Uyumunun Aracılık Rolü, İşletme Araştırmaları Dergisi, 11 (4), 2812-2823.

Eroğluer K. ve Kahraman Ç. A. (2019). Çalışanların Kişilik Özelliklerinin İşe Cezbolma Algıları Üzerine Etkisi: Bir Firma Uygulaması, Gazi İktisat ve İşletme Dergisi, 5(1): 21- 33.

Esen E. (2011). Çalışanların Örgüte Cezbolması, Marmara Üniversitesi İ.I.B.F. Dergisi, 30(1) 377-390.

Gorgievski, M.Y., Bakker, A.B., ve Schaufeli, W.B. (2010). Work Engagement and Workaholism: Comparing The Self-Employed and Salaried Employees, Journal of Positive Psychology, 5, 83-96.

Gül H. ve Erol M. (2016). Muhasebe Meslek Mensuplarında İşe Bağlılık Ve Çalışma Ahlakının Mesleki Etik Davranışa Etkisi, Mali Çözüm Dergisi, 137, 51-74.

Ertosun, O. G. \& Erdil, O. \& Alpkan, L. (2018). Pozitif Psikolojik Sermaye ve Çalışan Adanmışlığı İlişkisi Deneysel Bir Çalışma, BMIJ, 6(4): 1033-1052.

Güler M., Çetin F. ve Basım H. N. (2019). İşe Tutulma Ölçeği Çok Kısa Versiyonu (UWES-3) Geçerlilik ve Güvenilirlik Çalışması: Alternatif Bir Versiyon (UWES-6) Önerisi, İş ve İnsan Dergisi, 6(2), 189-197.

Güler M. ve Ocak M. (Yönlendirici Liderliğin Çalışan Performansına Etkisinde İşe Tutulmanın Aracılık Rolü, Toros Üniversitesi İISBF Sosyal Bilimler Dergisi, 6(11), 75- 85.

Güler M. (2019). Temel Benlik Değerlendirmesi Çalışanların Performansını Nasıl Etkiler? İşe Tutulmanın Aracılık Rolü, Ömer Halisdemir Üniversitesi İktisadi ve İdari Bilimler Fakültesi Dergisi, 12(1), 61-71.

Gürlek M. ve Tuna M. (2019). İşe Adanmanın Teorik Temelleri ve Ölçümü, Türk Psikoloji Yazıları, 22(44), 3549. 
F. N. Sayğan Yağız 13/1 (2021) 359-374

Gürlek M. (2020). Yüksek Performansı İnsan Kaynakları Uygulamaları Hizmet Odaklı Örgütsel Vatandaşlık Davranışını Nasıl Etkiler? İş Tutumlarının Aracılık Rolü, İş ve İnsan Dergisi, 7(1), $59-76$.

Godkin, L. (2014). Mid-Management, Employee Engagement, and the Generation of Reliable Sustainable Corporate Social Responsibility, Journal of Business Ethics, 130(1), 15-28.

Gupta, M. (2015). “Corporate Social Responsibility, Employee-Company Identification, and Organizational Commitment: Mediation by Employee Engagement", Current Psychology, 36(1), 101-109.

Han S.H., Sung M., Suh B. (2020). Linking Meaningfulness to Work Outcomes Through Job Characteristics and Work Engagement, Human Resource Development International, 1- 20.

Hanaysha, J. (2016). Improving employee productivity through work engagement: Evidence from higher education sector. Management Science Letters, (Ocak), 61-70.

Ibrahim M. ve Al Falasi S. (2014). Employee Loyalty And Engagement İn UAE Public Sector, Employee Relations, 36(5), 1-23.

İnce A. R. (2019). İşe Bağlılık ile İş Performans. Arasındaki İlişkide İş Zanaatkârlığının Aracılık Rolü:

Zanaatkârlar Üzerine Bir Araştırma, KOSBED, 38, 69- 84.

İnce A. R. (2016). Algılanan Örgütsel Desteğin İşe Adanmışlık Üzerindeki Etkisinde Yönetici Desteğinin Aracilık Rolü, Elektronik Sosyal Bilimler Dergisi, 15(57), 649-660.

İnce A.R. ve Topcu M.K. (2017). Girişimcilik Yöneliminin İşe Bağlanma Üzerindeki Etkisinde Algılanan Örgütsel Desteğin Rolü, Kara Harp Okulu Bilim Dergisi, 27(2), 1-27.

Işık M. ve Kama A. (2018). Algılanan Örgütsel Desteğin İşgören Performansına Etkisinde İşe Adanmışlı̆ı̆ın Aracı Etkisi, Anemon Muş Alparslan Üniversitesi Sosyal Bilimler Dergisi, 6(3), 395-403.

Kahn, W.A. (1990), Psychological conditions of personal engagement and disengagement at work, Academy of Management Journal, 33, 692-724.

Kanten P., Kanten S. ve Dündar G. (2016). Ücret Tatmininin ve İşin Özelliklerinin İşe Gömülmüşlük Üzerindeki Etkisinde Mutluluğun Rolü, İşletme Araştırmalar Dergisi, 8(3), 64-88.

Kanten P. ve Yeşiltaş M. (2013). Pozitif Örgütsel Davranışlar Üzerine Kavramsal Bir İnceleme, Süleyman Demirel Üniversitesi Vizyoner Dergisi, 4(8), 83-106.

Kaplanseren S. ve Örücü E. (2018). İşe Tutkunluğun Örgütsel Vatandaşlı̆ga Etkisi: Otel Çalışanları Üzerine Bir Araştırma, Trakya Üniversitesi İktisadi ve İdari Bilimler Fakültesi Dergisi, 7(1), 1-19.

Karagonlar ., Öztürk E.B. ve Özmen Ö. N. T. (2015). Çalışanın Örgütle Sosyal Mübadele Algısı Ve

İşten Ayrılma Niyeti: İşe Cezbolmanın ve Öz Yeterliliğin Rolü, ODTÜ Gelişme Dergisi, 42 (Aralık), 411-433.

Kartal H., İşler L. ve Bilişli Y. (2015). Örgütsel Bağlllık ve İşle Bütünleşmenin İşten Ayrılma Niyetine Etkisi: Çağrı Merkezi Örneği, Electronic Journal of Vocational Colleges, 14.BÜROKON Özel Sayısı, 325-338.

Kartal N. (2017). Sağlık Çalışanlarında İşe Cezbolma: Üniversite, Kamu ve Özel Hastanelerde Bir Uygulama, Hacettepe Sağllk İdaresi Dergisi, 20(3): 329-345.

Kayar Z. ve Erdem R. (2017). Hemşirelerde Ahlâkî Sıkıntının İşe Adanma Davranışı Üzerine Etkisi, Mehmet Akif Ersoy Üniversitesi Sosyal Bilimler Enstitüsü Dergisi, 9(22), 77-103.

Keleş S. (2014). Aile Şirketlerinde Y Jenerasyonunun Öz Yeterlilik Algısı ve İşe Adanmışlık İlişkisi, Süleyman Demirel Üniversitesi Vizyoner Dergisi, 5(11), 95-109.

Kerse G. ve Karabey C. N. (2019). Örgütsel Sinizm ve Özdeşleşme Bağlamında Algılanan Örgütsel Desteğin İşe Bağlanma ve Politik Davranış Algısına Etkisi, Eskişehir Osmangazi Üniversitesi İIBF Dergisi, 14( 1), 83108.

Kesen M. ve Akyüz B. (2016). Duygusal Emek ve Prososyal Motivasyonun İşe Gömülmüşlüğe Etkisi: Sağlık Çalışanları Üzerine Bir Uygulama, Ç.Ü. Sosyal Bilimler Enstitüsü Dergisi, 25(2), 233-250. 
F. N. Sayğan Yağız 13/1 (2021) 359-374

Kılıç K. C., Toker I. D., Karayel D., Soyman T. ve Zengin G. (2020). Paternalist ve Dönüşümsel Liderlik Tarzlarının İşe Adanmışlık Üzerindeki Etkisinde, Sıkılık-Esneklik Değişkeninin Aracılık Rolü, Uluslararası Toplum Araştırmaları Dergisi, 15(24), 2875-2911.

Koçak D. (2020). İş Özerkliği ile İşe Bağlanma Arasındaki İlişki: Kişi-İş Uyumunun Aracı ve Algılanan Yönetici Desteğinin Düzenleyici Rolü, Eskişehir Osmangazi Üniversitesi İiBF Dergisi, 15(2), 699 -718.

Kodaş B.(2018). Yiyecek İçecek Çalışanlarının Pozitif Psikolojik Sermayeleri ile İşe Angaje Olma Davranışları Arasındaki İlişki, Kırklareli Üniversitesi Sosyal Bilimler Dergisi, 2(1), 1-14.

Maden Eyiusta C. (2015). İşgörenlerin Güçlendirme Algılarının Sorumluluk Üstlenme Davranışları Üzerindeki Etkisi: İşe Adanmışlık ve İş Tatmini Değişkenlerinin Aracılık Rolü, Dumlupınar Üniversitesi Sosyal Bilimler Dergisi, 43, 68-78.

Maslach, C. ve Leiter, M. P. (2008). Early Predictors of Job Burnout and Engagement, Journal of Applied Psychology, 93(3), 498-512.

Ocak M. (2019). Liderlerin Karizmatik Davranışları Çalışanların İş Performansını Nasıl Etkiler? Çalışanların İşe Tutulma Düzeylerinin Aracılık Rolü, Uluslararası İktisadi ve İdari Bilimler Dergisi, 5 (1), 23-38.

Oprea, B., Păduraru, L., \& Iliescu, D. (2020). Job Crafting and Intent to Leave: The Mediating Role of Meaningful Work and Engagement, Journal of Career Development, 20(10), 1- 14.

Özyilmaz, A. ve Süner Z. (2015). İşe Adanmışlığın İşyeri Tutumlarına Etkisi: Hatay'daki 9 İşletmede Yapılan Ampirik Araştırmanın Sonuçları, Eskişehir Osmangazi Üniversitesi İibf Dergisi, 10(3), 143- 164

Öngöre Ö. (2019). Duygusal Emeğin İşle Bütünleşme Üzerindeki Etkisinin Belirlenmesine Yönelik Bir Araştırma: Hizmet Sektöründe Özel İşletme Çalışanları, İ̧̧ Ahlakı Dergisi, 12(1), 113-134.

Öngöre Ö. (2013). İşle Bütünleşme Ölçeği Türkçe Formu'nun Güvenilirlik Ve Geçerlilik Çalışması, Kastamonu University Journal of Economics \& Administrative Sciences Faculty, 2(1), 50-60.

Örücü E., Hatipoğlu S. (2018). Psikolojik Güçlendirmenin Çalışmaya Tutkunluk Üzerindeki Etkisi: Sağlık Sektörü Çalışanlarına Yönelik Bir Araştırma, Yönetim ve Ekonomi Araştırmaları Dergisi, 16(4), 98-115.

Örücü E. ve Uçku I. (2019). Örgütlerde İşe Tutkunluk, Örgütsel Destek Algısı, Örgütsel Vatandaşlık

Davranışı İlişkisi ve Bir Araştırma, Çă̆ Üniversitesi Sosyal Bilimler Dergisi, 16(2), 71-81.

Özaralli N. (2017). İşe tutkunluğun, yapisal güçlendirme, örgütsel özdeşleşme ve hedeflerin içselleştirilmesi yoluyla geliştirilmesi, International Journal of Social Sciences and Education Research, 3(4), 1258-1273.

Özer Ö., Saygılı M., Uğurluoğlu Ö. (2015). Sağlık Çalışanlarının İşe Cezbolma Düzeylerinin Belirlenmesine İlişkin Bir Araştırma, Business \& Management Studies: An International Journal, 3(3), 261-272,

Özer Topaloğlu E., Sönmez R. ve Yazgan A. E. (2019). Çalışmaya Tutkunluk ve İş Yaşam Dengesi Arasındaki İlişki: Banka Çalışanları Üzerine, Journal of BRSA Banking and Financial Markets, 13(1), 59-76.

Özeren E., Arslan A. ve Demirtaş Ö. (2019). İKY Uygulamalarının İşe Adanmışlık ve İş Yaşam Dengesi Üzerindeki Etkisi: Örgütsel Adalet Algısının Aracı, Kayırmacilığın Düzenleyici Rolü, Uluslararası Iktisadi ve İdari İncelemeler Dergisi, BOR Özel Sayı, 211-228.

Özgüleş B. (2019). İşe Bağlılık ve İş Yaşamında Mutluluk Kavramlarının Epistemik Olarak İncelenmesi, ASSAM Uluslararası Hakemli Dergi, 6(14), 72-81.

Özkalp E. ve Meydan B. (2015). Schaufeli ve Bakker Tarafından Geliştirilmiş Olan İşe Angaje Olma Ölçeğinin Türkçe'de Güvenilirlik ve Geçerliliğinin Analizi, İş,Güç Endüstri İlişkileri ve İnsan Kaynakları Dergisi, 17(3), 4-19.

Öztürk Anabal İ. ve Arıkan S. (2019). İş Yükü, İrritasyon ve Çalışmaya Tutkunluk İlişkisinde Alıgılanan Yönetici Desteği ve Pozitif Psikolojik Sermaye Biçimleyici midir?, İş'te Davranış Dergisi, 4(1), 25-45.

Öztürk Çiftçi D. (2019). Lider Üye Etkileşiminin İşe Adanmışlık Üzerindeki Etkisinde Psikolojik Güçlendirmenin Aracı Rolü, Business and Economics Research Journal, 10(1), 167-186. 
F. N. Sayğan Yağız 13/1 (2021) 359-374

Parzefall, M.R., ve Hakanen, J. (2010). Psychological Contract and Its Motivational and Health- Enhancing Properties. Journal of Managerial Psychology, 25, 4-21.

Polat Ö., Tuysuz M., ve Yener R. (2018). Çalışmaya Tutkunluğun Motivasyona Etkisi: Türkiye'deki Vakıf Üniversitesi Kütüphaneleri Örneği, Uşak Üniversitesi Sosyal Bilimler Dergisi, 11(3), 191-206.

Rayton, B.A. and Yalabik, Z.Y. (2014). Work Engagement, Psychological Contract Breach and Job Satisfaction. International Journal of Human Resource Management. 25, 2382-2400.

Seçkin Ş. N. (2018). Yapılan İşin Anlamlılığı ve İşe Tutkunluk İlişkisi Akademisyenler Üzerine Bir Araştırma, ÇAKÜ Sosyal Bilimler Enstitüsü Dergisi, 9(1), 143-160.

Şahin S. ve Çankır B. (2018). İş Tatmininin İş Performansına Etkisinde Çalışmaya Tutkunluğun Aracı Rolü: Satış ve Pazarlama Sektöründe Bir Araştırma, Uluslararası İktisadi ve İdari İncelemeler Dergisi, 17. UIK Özel Sayıs1, 389-402.

Şahin S. ve Çankır B. (2019). Sürdürülebilir Kalite Algısı ve İş Performansı: Çalışmaya Tutkunluğun Aracı Rolü, Ç.Ü. Sosyal Bilimler Enstitüsü Dergisi, 28(3), 196-211.

Şahin S., Yozgat U. ve Yakşi E. (2018). Çalışmaya Tutkunluk Düzeyinin Hastane Türü Hastane Lokasyonu Ve Bazı Sosyo- Demografik- Mesleki Özelliklere Göre İncelenmesi, İşletme Bilimi Dergisi, 6(1), 163- 183.

Şahinbaş F.ve Erigüç G. (2019). Pozitif Örgütsel Davranış Yaklaşımıyla İşyeri Arkadaşlığı Ve İşe Adanma İlişkisi: Sağlık Çalışanları Üzerine Bir Araştırma, Uluslararası Yönetim İktisat ve İşletme Dergisi, 15(4), 1201-1225.

Saks A.M. (2006). Antecedents and consequences of employee engagement, Journal of Managerial Psychology, 21(7), 600-619.

Sayğan Tunçay S., Süral Özer P. ve Tozkoparan G. (2015). Yerel Yazında Sosyal Sermaye Araştırmaları: Odaklar ve Boşlukların Sosyal Ağ Analizi ile İncelenmesi, İşletme Fakültesi Dergisi, 16(2), 71-89.

Schaufeli, W.B., Salanova, M., Gonzalez-Romá, V. ve Bakker, A. B. (2002). The Measurement of Engagement and Burnout: A Confirmative Analytic Approach, Journal of Happiness Studies, 3, 71-92.

Schaufeli, W.B. ve Bakker, A.B. (2010). Defining and Measuring Work Engagement, Bringing Clarity to the Concept, İçinde A;B; Bakker and M;P; Leiter (Eds;), Work Engagement, A Hand Book of Essential Theory and Research (ss.10-24), New York Psychology Press.

Şen N. (2019). Liderlik Özelliklerinin İşe Tutkunluk Üzerindeki Etkisine Yönelik Bir Araştırma, BEÜ İIBF AİD., 4(2), 264-282.

Turan M. F. ve Özdemir Y. (2019). İş Şekillendirme ve İşe Adanmışlık Arasındaki İlişki: İlaç Sektöründe Satış Pazarlama Profesyonelleri Üzerinde Yapılan Bir Araştırma, İşletme Araştırmaları Dergisi, 11(3), 13461357.

Turgut E. ve Beğenirbaş M. (2016). Türkiye'deki Örgütsel Davranış Yazınına Bakış: Örgütsel Davranış Kongrelerinin Yazar ve İçerik Yönünden A $\breve{g}$ Analizi ile İncelenmesi, Gazi Üniversitesi İktisadi ve İdari Bilimler Dergisi, 18(1), 328-354.

Turgut T. (2013). Başarı Hedef Yönelimleri ve İş Özelliklerinin Çalışmaya Tutkunluk Üzerindeki Katkıları, İstanbul Üniversitesi İşletme Fakültesi Dergisi, 42(1), 1-25.

Turgut T. (2011). Çalışmaya Tutkunluk: İş Yükü, Esnek Çalışma Saatleri, Yönetici Desteği ve İş-Aile Çatışması ile İlişkileri, Atatürk Üniversitesi İktisadi ve İdari Bilimler Dergisi, 25(3-4), 155- 179.

Ulukök E., Akın A. ve Gökdeniz İ. (2017). Algılanan Fazla Niteliklilik, İşe Adanmışlık Ve İşten Ayrılma Niyeti Arasındaki İlişkinin İncelenmesi: Bankacılık Sektöründe Bir Araştırma, Uluslararası Sosyal Araştırmalar Dergisi, 10(54), 917- 923.

Uyar, S. ve Güzel, Ş. (2019). İşe Angaje Olmak Kavramı, Tükenmişlik ile İlişkisi ve Sonuçları, Sosyal Araştırmalar ve Yönetim Dergisi, (1), 44-52. 
Yolcu Uncuoğlu İ. ve Çakmak A.F (2017), Proaktif Kişilik İle Proaktif Çalışma Davranışı Arasındaki İlişkide İşe Gönülden Adanmanın Aracı Etkisi, BMIJ, (2017), 5(4): 76-96.

Uysal B., Özçelik G. ve Uyargil C. (2018). Bireysel İş Yapılandırmanın Sonuçları: Bireysel İş Yapılandırmanın Psikolojik Sermaye Ve İşe Adanmışlık Üzerindeki Etkisinin Değerlendirilmesi, Yönetim Bilimleri Dergisi, 16(32), 651-666.

Ülbeği İ. D., İplik E. ve Yalçın A. (2018). Etik Liderliğin İş Tatmini ve İşten Ayrılma Niyetine Etkisinde İşe Adanmanın Rolü, Sayıştay Dergisi, 29(111), 173- 195.

Vatansever Durmaz İ. B. (2019). Havayolu Yolcu Taşımacıllğı Sektöründe Algılanan Stres Ve İşle Bütünleşme Arasındaki İlişkinin İşten Ayrılma Kararına Etkisi, Al-Farabi International Journal on Social Sciences, 3(1), 59-69.

Wasserman, S. ve Faust, K. (1994). Social Network Analysis: Methods and Applications, America: Cambridge University Press.

Yener S. (2019). Kadın Çalışanların Cinsiyet Rol Stresi ve İşe Adanmışlıkları Arasındaki İlişkide Yaşam Kalitesinin Düzenleyici Rolü, İşletme Fakültesi Dergisi, 20(1), 1-27.

Yeşil S. ve Mavi Y. (2018). Duygusal Emeğin Etkilediği Faktörler Üzerine Bir Alan Araştırması, Aksaray Üniversitesi İktisadi Ve İdari Bilimler Fakültesi Dergisi, 10(1), 29-44.

Yıldız R. Ö., Baran E. ve Ayaz İ. S. (2017). The Effect Of Organızatıonal Trust On Work Engagement: An Application on Logistıcs Personnel, The International New Issues in Social Sciences, 5(5), 139- 158.

Zor M. (2019). Psikolojik Sağlamlığın ve Genel Öz yeterliliğin Çalışmaya Tutkunluğa Etkisinin Karşılaştırılması, Yorum Yönetim Yöntem, 7(1), 35-44. 